\title{
PERSEPSI GURU PENDIDIKAN AGAMA KRISTEN INDONESIA TERHADAP PEMBELAJARAN ONLINE DI TENGAH COVID-19 DAN ERA INDUSTRI 4.0
}

\author{
Jenri Ambarita, ${ }^{1}$ Ester Yuniati, ${ }^{2}$ Nurmiani Sinaga ${ }^{3}$ \\ Institut Agama Kristen Negeri Ambon, ${ }^{1}$ SMTK Kristo Manado, ${ }^{2}$ \\ SMP Negeri 54 Batam $^{3}$ \\ jenriambarita7@gmail.com, ${ }^{1}$ esteryuniati7@gmail.com, ${ }^{2}$ nurmiani710@gmail.com ${ }^{3}$
}

\begin{abstract}
Abstrak
Penelitian ini bertujuan untuk mendeskripsikan persepsi-persepsi guru Pendidikan Agama Kristen terhadap pembelajaran online yang dilaksanakan pada masa pandemi Covid-19. Persepsi-persepsi guru PAK yang meliputi aspek kemudahan penggunaan, aspek kemudahan dalam membangun komunikasi, aspek dampaknya terhadap motivasi guru dalam mengajar, motivasi untuk meningkatkan kreatifitas guru, dan motivasi guru dalam meningkatkan keterampilannya dalam memanfaatkan TIK. Subyek penelitian adalah guru PAK Indonesia yang bergabung pada grup telegram yang beranggotakan 662 orang. Pengumpulan data dilakukan dengan penyebaran angket berupa kusioner online dalam bentuk google formulir. Penelitian ini merupakan penelitian campuran (mix methode). Penelitian campuran yang dimaksud dalam tulisan ini adalah data penelitian dari penyebaran angket akan disajikan dalam bentuk statistik sebagai data kuantitatif dan sajian data kuantitaif tersebut akan dideskripsikan sebagai data kualitatif. Adapun hasil dari penelitian ini adalah guru PAK yang berada di daerah dengan akses internet kurang lancar, guru yang belum pernah mengikuti PPG ataupun kegiatan workshop pembelajaran online selalu merasa bahwa pembelajaran online itu sulit untuk diterapkan. Dengan demikian, guru pendidikan Agama Kristen lebih memilih pemberian tugas kepada peserta didik. Guru Pendidikan Agama Kristen yang berada di daerah dengan akses internet lancar, guru PAK yang sudah pernah mengikuti PPG dan kegiatan pelatihan pembelajaran online merasa bahwa pembelajaran online mudah untuk diterapkan, bahkan guru PAK memiliki pandangan bahwa pelaksanaan pembelajaran online memberikan motivasi yang positif terhadap guru untuk semakin kreatif, semakin terampil dalam memanfaatkan TIK dalam pembelajaran.
\end{abstract}

Kata kunci: Persepsi, Guru Pendidikan Agama Kristen, Covid-19, Era Industri 4.0

\begin{abstract}
This study aims to describe the perceptions of Christian Religious Education teachers towards online learning carried out during the Covid-19 pandemic. PAK teachers' perceptions include aspects of ease of use, aspects of ease in building communication, aspects of its impact on teacher motivation in teaching, motivation to increase teacher creativity, and motivation of teachers to improve their skills in utilizing
\end{abstract}


ICT. The research subjects were Indonesian PAK teachers who joined a telegram group which had 662 members. The data was collected by distributing questionnaires in the form of online questionnaires in the form of google forms. This research is a mixed research (mix method). The mixed research referred to in this paper is that the research data from the distribution of questionnaires will be presented in statistical form as quantitative data and the quantitative data presentation will be described as qualitative data. The results of this study are PAK teachers who are in areas with less smooth internet access, teachers who have never attended PPG or online learning workshops always feel that online learning is difficult to implement. Thus, Christian religious education teachers prefer to assign assignments to students. Christian Religious Education teachers who are in areas with smooth internet access, PAK teachers who have participated in PPG and online learning training activities feel that online learning is easy to implement, even PAK teachers have the view that the implementation of online learning provides positive motivation for teachers to be increasingly creative, increasingly skilled in utilizing ICT in learning.

Keywords: Perception, Christian Religious Education teachers, Covid-19, Industrial Era 4.0

\section{Pendahuluan}

Pendidikan merupakan modal penting bagi kemajuan dan pembangunan suatu bangsa guna meningkatkan daya saing terhadap tantangan kemajuan zaman. ${ }^{1}$ Salah satu tujuan Bangsa Indonesia yang tercantum dalam Pembukaan UUD 1945 adalah mencerdaskan kehidupan bangsa. Untuk mewujudkan cita-cita tersebut, Indonesia harus mempersiapkan pendidikan yang bermutu.

Pendidikan yang bermutu akan menghasikan sumber daya manusia yang berkualitas dan mempunyai daya saing tinggi dengan bangsa lain. Membangun SDM yang pekerja keras, dinamis, terampil, menguasai ilmu pengetahuan dan teknologi menjadi prioritas utama pemerintah sebagaimana disampaikan oleh Presiden Joko Widodo

\footnotetext{
1 Erna Pujiasih, "Membangun Generasi Emas Dengan Variasi Pembelajaran Online Di Masa Pdanemi Covid-19 Building A Golden Generation By Applying Various Online Learning In The Pdanemi Of Covid-19," Jurnal Karya Ilmiah Guru Vol.5, No. 1 (2020): 42-48.
}

dalam pidato pada sidang paripurna MPR RI. ${ }^{2}$ Oleh karena itu, Negara Indonesia membutuhkan guru-guru yang kompeten untuk menghasilkan SDM yang diharapkan.

Virus corona membawa dampak yang besar terhadap segala aspek kehidupan manusia, tidak terkecuali dengan bidang pendidikan. Untuk mencegah penyebaran virus tersebut, sejumlah negara yang terdampak menerapkan pembelajaran jarak jauh dengan memanfaatkan teknologi. ${ }^{3}$ Demikian juga dengan Indonesia mengeluarkan kebijakan belajar dari rumah pada masa darurat covid-19

\footnotetext{
2 "Naskah Pidato Sesuai Pengucapan Presiden Joko Widodo Di Depan Sidang Paripurna Mpr Ri," Kompas.Com, Last Modified 2019, Https://Jeo.Kompas.Com/Naskah-LengkapPidato-Presiden-Joko-Widodo-Dalam-PelantikanPeriode-2019-2024.

${ }^{3}$ Ali Sadikin dan Afreni Hamidah, "Pembelajaran Daring Di Tengah Wabah Covid-19," Biodik Vol.6, No.2 (2020): 109-119; Firman Firman dan Sari Rahayu, "Pembelajaran Online di Tengah Pdanemi Covid-19," Indonesian Journal Of Educational Science Vol.2, No. 2 (2020).
} 
dengan tujuan untuk memastikan hak belajar anak tetap terpenuhi dan kesehatan anak tetap terjamin. ${ }^{4}$

Pembelajaran online menjadi solusi alternative yang banyak diterapkan oleh lembaga pendidikan, karena bisa dilaksanakan kapan saja dan di mana saja. Pembelajaran online merupakan model pembelajaran yang memanfaatkan jaringan internet dan perangkat elektronik seperti android, komputer, dan lainnya. ${ }^{5}$

Pembelajaran online menuntut siswa, guru bahkan orang tua melek dengan teknologi. ${ }^{6}$ Siap atau tidak siap, mau atau tidak mau, teknologi harus dimanfaatkan. ${ }^{7}$ Masyarakat harus keluar dari persepsi lama terhadap kemajuan teknologi dan harus adaptif terhadap perkembangan zaman. Persepsi para pendidik, peserta didik atau orang tua akan memperngaruhi keberhasilan pembelajaran online. ${ }^{8}$

4 Kemendikbud Republik Indonesia, "Surat Edaran Nomor 14 2019” (2019): 2.

5 Roida Pakpahan dan Yuni Fitriani, "Analisa Pemanfaatan Teknologi Informasi dalam Pembelajaran Jarak Jauh di Tengah Pdanemi Virus Corona Covid-19," Journal Of Information System, Applied, Management, Accounting Dan Research Vol.4, No.2 (2020); Ervan Wicaksana, "Efektifitas Pembelajaran Menggunakan Moodle Terhadap Motivasi Dan Minat Bakat Peserta Didik Di Tengah Pdanemi Covid -19," Eduteach : Jurnal Edukasi Dan Teknologi Pembelajaran Vol.1, No.2 (2020); Dwi Priyanto, "Pengembangan Multimedia Pembelajaran Berbasis Komputer," Vol.14, No.1 (2009): 1-13.

6 Jenri Ambarita, Muthoharoh, dan Ester Yuniati, "Persepsi Masyarakat Terhadap Penggunaan Teknologi dalam Seminar Online di Masa Covid19," Indonesian Journal Of Instructional Vol.1 (2020): 1-8.

${ }^{7}$ Jenri Ambarita, Hendra Helwaun, dan Lauraincia Van Houten, "Workshop Pembuatan E-Book Sebagai Bahan Ajar Elektronik Interaktif Untuk Guru Indonesia Secara Online di Tengah Covid 19," Community Engagement \& Emergence Journal Vol.2, No.1 (2020): 44-57.

${ }^{8}$ A.Z. Abidin, T. Puspasari, dan W.A. Nugroho, "Polymers For Enhanced Oil Recovery
Robbin dalam Fauziah $^{9}$ mengatakan bahwa persepsi merupakan suatu proses mengorganisasikan atau menafsirkan lingkungannya dengan penilaiannya sendiri. Setiap individu pasti memiliki suatu persepsi terhadap lingkungannya namun persepi suatu individu terhadap suatu obyek sangat mungkin memiliki perbedaan dengan persepsi individu lainnya terhadap obyek yang sama.

Era Industri 4.0 merupakan era digital yang memadukan kemajuan teknologi untuk membantu segala aktifitas kehidupan masyarakat, perpaduan teknologi ini mengakibatkan perpaduan digital yang sangat sulit untuk dibedakan sebagaimana dikatakan oleh Scawab dalam ${ }^{10}$ Perkembangan teknologi di era industri 4.0 saat ini telah banyak membawa dampak besar terhadap banyak aspek kehidupan manusia, tidak terkecuali dengan dunia pendidikan. Teknologi merupakan bagian terpenting dalam pendidikan saat ini, teknologi menjadi hal yang sangat banyak mempengaruhi. Hal ini dipengaruhi oleh dampak teknologi yang membuat pembelajaran menjadi lebih efektif, efesien dan sangat ekonomis. ${ }^{11}$

Pendidikan abad 21 ditandai dengan pemanfaatan teknologi dalam pembelajaran sebagai tuntutan era industri 4.0. ${ }^{12}$

Technology," Procedia Chemistry Vol.4 (2012): 11-16.

${ }^{9}$ Fauziah Wahyuning Tias, "Perlukah Mahasiswa Akuntansi Strata Satu Akuntansi Di Indonesia Memiliki Persepsi Audit Forensik," Jurnal Akuntansi Unesa Vol.1, No.1 (2012): 1-20.

${ }^{10}$ Susilahudin Putrawangsa dan Uswatun Hasanah, "Integrasi Teknologi Digital dalam Pembelajaran di Era Industri 4.0," Jurnal Tatsqif 16, No. 1 (2018): 42-54.

${ }^{11}$ Putrawangsa dan Hasanah, "Integrasi Teknologi Digital dalam Pembelajaran di Era Industri 4.0," 42-54.

${ }^{12}$ Pakpahan dan Fitriani, "Analisa Pemanfaatan Teknologi Informasi dalam Pembelajaran Jarak Jauh di Tengah Pdanemi Virus Corona Covid-19": 
Pemanfaatan teknologi (IPTEK) sudah sangat banyak digunakan untuk menyelesaikan permasalahan dalam bidang pendidikan. ${ }^{13}$ Namun, dalam penelitian yang dilakukan oleh Iskarim mengatakan bahwa kemajuan IPTEK dinilai belum mampu atau belum banyak dimanfaatkan untuk menumbuhkan moral para penggunanya. ${ }^{14}$ Pernyataan ini semakin dikuatkan oleh Ningrum yang mengatakan bahwa kemajuan teknologi sangat banyak disalahgunakan oleh para remaja (pelajar) untuk hal yang kurang bermanfaat. $^{15}$

Pendidikan Agama Kristen bukanlah satu-satunya mata pelajaran inti untuk membentuk akhlak peserta didik, namun Pendidikan Agama Kristen menjadi bagian yang tidak bisa diabaikan dalam kehidupan peserta didik. Pendidikan Agama Kristen hadir bukan saja untuk memperlengkapi pengetahuan akademik, namun juga mengajarkan nilai-

Dwi Yunita dan Astuti Wijayanti, "Pengaruh Media Video Pembelajaran Terhadap Hasil Belajar IPA Ditinjau dari Keaktifan Siswa," Sosiohumaniora: Jurnal Ilmiah Ilmu Sosial Dan Humaniora Vol.3, No. 2 (2017): 153-160; Jason Mcgrath Dan John Fischetti, "What If Compulsory Schooling Was A 21st Century Invention? Weak Signals From A Systematic Review Of The Literature," International Journal Of Educational Research 95, No. November 2018 (2019): 212-226,

Https://Doi.Org/10.1016/J.Ijer.2019.02.006.

${ }^{13}$ Ambarita, Helwaun, dan Houten, "Workshop Pembuatan E-Book Sebagai Bahan Ajar Elektronik Interaktif untuk Guru Indonesia Secara Online di Tengah Covid 19."

${ }^{14}$ Mochammad Iskarim, "Dekadensi Moral Di Kalangan Pelajar (Revitalisasi Strategi Pai Dalam Menumbuhkan Moralitas Generasi Bangsa)," Edukasia Islamika Vol.1, No.1 (2016): 1-20.

15 Diah Ningrum, "Kemerosotan Moral Di Kalangan Remaja: Sebuah Penelitian Mengenai Parenting Styles dan Pengajaran Adab Diah Ningrum Sekolah Menengah Islam Terpadu (Smit) Al Marjan," Unisia Xxxvii, No. 82 (2015): 18-30. nilai kristiani yang bersumber dari Alkitab. ${ }^{16}$

Pendidikan Agama Kristen memiliki tanggung jawab terhadap akhlak peserta didik terkhusus bagi peserta didik yang beragama Kristen, karena melalui pembelajaran Agama peserta didik memiliki karakter yang sesuai harapan. Itu sebabnya esensi Pendidikan Agama Kristen harus mengutamakan dimensi karakter. ${ }^{17}$

Untuk mencapai tujuan pendidikan tersebut dibutuhkan peran seorang pendidik dalam menyampaikan nilai-nilai penting yang terkandung di dalam pembelajaran PAK tersebut. Oleh karena itu, dibutuhkan guru yang tidak hanya memiliki kemampuan akademik yang baik saja, melainkan juga memiliki nilai-nilai kerohanian yang baik. Guru PAK adalah seorang yang sudah lahir baru yang akan berperan penting dalam pembentukan karakter siswa melalui pengenalan dan ketaatan pada Kristus sebagaimana dikatakan oleh knight dalam $^{18}$ Proses penyampaian nilai-nilai kristiani kepada peserta didik terjadi dengan adanya interaksi yang baik antara guru dan siswa, baik interaksi dalam pembelajaran di kelas ataupun interaksi di luar pembelajaran. karena itu, seorang guru harus memiliki kreatifitas dan keterampilan dalam merancang dan menerapkan metode pembelajaran yang digunakan, karena kualitas metode pembelajaran yang dipilih oleh guru akan

\footnotetext{
16 Kiki Debora dan Chdanra Han, "Pentingnya Peranan Guru Kristen dalam Membentuk Karakter Siswa dalam Pendidikan Kristen: Sebuah Kajian Etika Kristen," Diligentia: Journal Of Theology Dan Christian Education Vol.2, No. 1, (January 2020): 1-14.

17 Daniel Nuhamara, "Pengutamaan Dimensi Karakter Dalam Pendidikan Agama Kristen," Jurnal Jaffray Vol.16, No. 1 (2018): 93.

18 Debora dan Han, "Pentingnya Peranan Guru Kristen dalam Membentuk Karakter Siswa Dalam Pendidikan Kristen: Sebuah Kajian Etika Kristen.”
} 
berpengaruh terhadap hasil yang dicapai oleh peserta didik dalam belajar. ${ }^{19}$

Pembelajaran online yang diterapkan sejak kehadiran wabah covid19 telah banyak dikaji oleh para peneliti dan permasalahan yang ditemukan cukup beranekaragam. Sebelum kemunculan virus korona, sesungguhnya sudah banyak lembaga pendidikan di Indonesia yang sudah menerapkan pembelajaran online atau daring, salah satunya adalah Universitas Terbuka (UT). ${ }^{20}$ Sebelum kehadiran Covid-19, telah banyak penelitian yang yang dilakukan untuk mengkaji dan menganalisis persepsi masyarakat tentang penerapan pembelajaran online di masa pandemi covid-19, baik persepsi dari peserta didik, pengajar atau bahkan dari sudut pandang orang tua ${ }^{21}$. Namun demikian, penelitianpenelitian terdahulu tidak banyak dilakukan terhadap guru Pendidikan Agama Kristen, bahkan belum pernah dilakukan secara kusus untuk melihat pandangan para guru Pendidikan Agama Kristen terhadap penerapan pembelajaran daring di Era Industri 4.0.

19 Dina Utami, "Efektifitas Animasi Dalam Pembelajaran," Majalah Ilmiah Pembelajaran 7, No. 1 (2011): 44-52.

20 Tri Darmayanti, Made Yudhi Setiani, dan Boedhi Oetojo, "E-Learning Pada Pendidikan Jarak Jauh: Konsep Yang Mengubah Metode Pembelajaran Di Perguruan Tinggi di Indonesia," Jurnal Pendidikan Terbuka Dan Jarak Jauh 8 (2007): 99-113.

${ }^{21}$ Suwarto Suwarto dan Hulman Fajri, "Persepsi Orang Tua Terhadap Proses Bimbingan Belajar Anak Di Rumah," Susunan Artikel Pendidikan Vol.3, No.1 (2018); Harapan Dosen Et Al., "Ecogen Penggunaan Media Pembelajaran Berbasis E-Learning Studi Persepsi dan Harapan Dosen dan Mahasiswa Ecogen Penggunaan Media Pembelajaran Berbasis E-Learning Studi Persepsi Dan Harapan Dosen dan Mahasiswa" 1 (2018); Much. Fuad Saifuddin, "E-Learning dalam Persepsi Mahasiswa," Jurnal Varidika Vol.29, No.2 (2018): 102-109.

\section{Metode Penelitian}

Penelitian dilaksanakan secara online dengan menggunakan google formulir. Subjek penelitian ini adalah guru-guru PAK Indonesia yang tergabung dalam grup telegram guru PAK Indonesia dengan jumlah anggota 662 orang. Adapun klasifikasi guru PAK yang menjadi informan dalam penelitian ini adalah 204 orang guru PAK di Sekolah Dasar, sebanyak 183 orang guru PAK mengajar di tingkat SMP dan sebanyak 195 orang guru PAK yang mengajar di tingkat SMA/K. Fokus pada penelitian ini adalah analisis persepsi guru PAK terhadadap pembelajaran online di masa pandemi Covid-19. Penelitian ini merupakan penelitian campuran (mix methods). Penelitian campuran atau mix methods merupakan suatu langkah penelitian dengan menggabungkan dua bentuk pendekatan dalam penelitian, yaitu kualitatif dan kuantitatif. Penelitian campuran merupakan pendekatan penelitian yang mengkombinasikan antara penelitian kualitatif dengan penelitian kuantitatif. Penelitian campuran yang dimaksud dalam tulisan ini adalah, data penelitian dari penyebaran angket akan disajikan dalam bentuk statistik sebagai data kuantitatif dan sajian data kuantitaif tersebut akan dideskripsikan sebagai data kualitatif. Penelitian ini hanya terbatas pada analisis persepsi guru Pendidikan Agama Kristen terhadap pembelajaran daring/online. Data-data penelitian dikumpulkan menggunakan kuesioner dan pengamatan. Kusioner yang disebar secara online ditanggapi oleh 582 orang guru PAK yang tersebar di seluruh Indonesia yang kemudian ditetapkan 
sebagai responden utama penelitian. Kusioner terdiri dari 5 (lima) kusioner yang terdiri dari Perepsi guru Pendidikan Agama Kristen terhadap kemudahan penggunaan pembelajaran online, persepsi guru Pendidikan Agama Kristen terhadap kemudahan dalam membangun komunikasi, persepsi guru PAK dari aspek dampak pembelajaran online terhadap motivasi guru dalam mengajar, aspek pembelajaran online terhadap motivasi guru untuk semakin kreatif dan aspek dampak pembelajaran online terhadap motivasi guru untuk meningkatkan keterampilan TIKnya dalam mengajar. Data-data yang terkumpul dianalisa menggunakan analisis statistik deskriptif yang berupa deskriptif persentase yang menunjukkan tingkat persepsi.

\section{Hasil dan Pembahasan}

Tujuan dari penelitian ini adalah untuk menelaah atau mendeskripsikan persepsi guru Pendidikan Agama Kristen Indonesia terhadap pembelajaran online pada masa pandemi covid-19. Persepsi guru Pendidikan Agama Kristen akan digali dalam beberapa aspek, antara lain : aspek kemudahan pelaksanaan pembelajaran online, aspek kemudahan dalam membangun komunikasi, aspek dampak pembelajaran online terhadap motivasi guru PAK dalam mengajar, aspek kampak pembelajaran online terhadap motivasi guru Pak untuk meningkatkan kreatifitas guru PAK dan aspek dampak pembelajaran online terhadap motivasi guru PAK untuk meningkatkan keterampilannya dalam memanfaatkan TIK dalam pembelajaran.

Berdasarkan data persepsi yang telah diperoleh melalui angket yang disebar secara online, maka diperoleh data sebagai berikut:

\section{A. Persepsi Guru PAK terhadap kemudahan pembelajaran online}

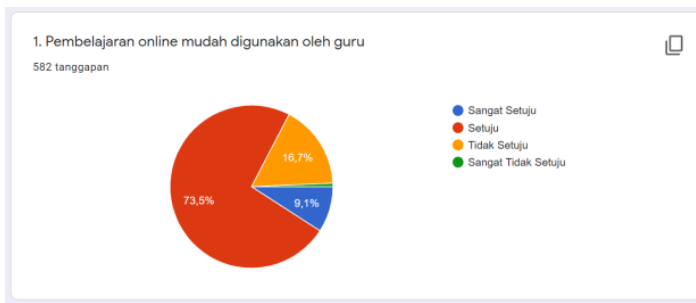

Gambar 1. Rekapitulasi data penelitian persepsi guru PAK terhadap kemudahan penggunaan pembelajaran online periode April-Juni 2020

Aspek kemudahan yang dimaksud dalam tulisan ini adalah kemudahan guru Pendidikan Agama Kristen mulai dari mempelajari sistem pembelajaran online yang akan digunakan, mengoperasikannya ataupun menerapkan pembelajaran daring. Kemudahan menerapkan pembelajaran yang dimaksud mulai dari upload materi, penyampaian materi, diskusi, absensi peserta didik, pemberian tugas, pemberian evaluasi pembelajaran yang dilaksanakan secara online.

Platform pembelajaran online yang digunakan oleh guru PAK sangat variatif satu dengan yang lainnya. Guru Pendidikan Agama Kristen memilih platform pembelajaran yang digunakan berdasarkan kemudahan atau kebiasaan guru dalam pembelajaran. Ada yang menggunakan google classroom, schoology, edmodo, bahkan ada yang menggunakan pembelajaran online berbasis media sosial seperti facebook, instagram dan blog. Lebih lanjut guru Pendidikan Agama Kristen mengatakan bahwa setiap platform pembelajaran online yang tersedia memiliki kelebihan dan kekurangannya masing-masing. Dan setiap guru memiliki pandangan yang berbeda sehingga mereka lebih memilih menggunakan platform tertentu sesuai 
dengan kenyamanan guru dan peserta didik menggunakannya. Namun, mereka lebih menekankan didalam kemudahan penggunaannya. Sedangkan pembelajaran online untuk video conference, para pendidik labih banyak memanfaatkan aplikasi zoom, google meet, bahkan melaksanakan video call dengan aplikasi whatshaap.

Berdasarkan gambar $1 \mathrm{di}$ atas menunjukkan bahwa dari 582 orang guru Pendidikan Agama Kristen yang bersedia mengisi kusioner yang dibagikan terdapat $9,1 \%$ atau sebanyak 53 orang guru Pendidikan Agama Kristen yang mengatakan Sangat Setuju bahwa pembelajaran online itu mudah untuk diterapkan dan ada 73,5\% atau sebanyak 428 orang guru Pendidikan Agama Kristen yang memiliki persepsi Setuju bahwa pembelajaran online mudah untuk digunakan. Guru Pendidikan Agama Kristen yang mengatakan sangat setuju dan setuju bahwa pembelajaran online mudah digunakan, memiliki semangat dan motivasi yang tinggi dalam pembelajaran. Setidaknya ada tiga aspek yang mempengaruhi sikap positif guru PAK tersebut terhadap pembelajaran online, di antaranya:

Pertama, Guru Pendidikan Agama Kristen berada di daerah dengan akses internet relative lancar. Pembelajaran online akan terlaksana dengan baik jika didukung oleh akses internet yang baik. Kondisi daerah yang memiliki akses internet baik tentunya sangat mendukung untuk melaksanakan pembelajaran online pada masa darurat covid-19. Para pendidik tidak akan kesulitan dalam memahami cara pengguanan platform pembelajaran online, karena para peserta didik dan para pendidik dengan bebas mengakses, dan melihat di internet secara mandiri.

Kedua, Sebagian besar responden sudah pernah mengikuti Program Profesi
Guru (PPG). Kegiatan PPG guru Pendidikan Agama Kristen pada dua tahun terakhir, dilaksanakan selama enam bulan yang dibagi dalam dua metode pembelajaran, yaitu pembelajaran daring dan luring. Pembelajaran daring dilaksanakan selama tiga bulan dari daerah masing-masing, sedangkan tiga bulan selanjutnya dilaksanakan secara luring atau luar jaringan. Kegiatan luring dilaksanakan di Kota Ambon untuk kegiatan Lokakarya hingga kegiatan UKIN dan UP. Pengalaman pembelajaran online selama mengikuti perkuliahan program profesi guru menjadi modal yang sangat penting bagi seorang guru Pendidikan Agama Kristen pada masa darurat wabah virus corona. Selain itu, peserta PPG juga diperlengkapi dengan keterampilan dalam pemanfaatan TIK untuk mendukung pelaksanaan proses belajar mengajar. Dengan demikian, pembelajaran berbasis TIK sudah sangat familiar di kalangan guru Pendidikan Agama Kristen.

Ketiga, Guru Pendidikan Agama Kristen selalu pro aktif dalam berbagai kegiatan pelatihan atau workshop pengembangan kompetensi guru baik secara online maupun tatap muka. sehingga guru Pendidikan Agama Kristen sudah sangat familiar dengan berbagai teknologi media pembelajaran, bahkan sudah terbiasa menggunakannya ketika mengajar di kelas. Kondisi ini membuat guru Pendidikan Agama Kristen sudah melek dengan teknologi dan sudah familiar dengan pembelajaran online sebelumnya. Ini menjadi modal penting yang dimiliki oleh guru Pendidikan Agama Kristen, sehingga ketika pembelajaran di masa darurat covid-19 mereka tidak menghadapi kesulitan yang menghambat tugasnya sebagai guru. Dengan demikian, guru Pendidikan Agama Kristen tetap mampu melaksanakan pembelajaran online 
dengan bantuan perangkat dan akses internet yang mendukung.

Dari gambar di atas juga menunjukkan bahwa ada 16,7 \% atau sebanyak 97 orang yang mengatakan Tidak Setuju dan ada 0,7\% atau sebanyak 4 orang yang mengatakan Sangat Tidak setuju. Sebanyak $17,4 \%$ guru Pendidikan Agama Kristen yang masuk dalam kategori tidak setuju mengatakan bahwa pembelajaran online itu sulit bahkan sangat sulit untuk diterapkan. Dari 582 orang responden, ada sebanyak 111 orang yang mengatakan sulit bahkan sangat sulit. Lebih lanjut guru Pendidikan Agama Kristen merasa kesulitan dipengaruhi oleh beberapa faktor, di antaranya:

Pertama, beberapa guru Pendidikan Agama Kristen berada di daerah dengan akses internet yang kurang mendukung. Kondisi ini sangat mempengaruhi kepuasan seseorang ketika melaksanakan proses belajar-mengajar, karena akan tidak bisa berjalan dengan efektif. Kondisi ini berdampak terhadap menurunnya semangat guru PAK dalam melaksanakan pembelajaran online. Guru PAK menjadi kurang termotivasi untuk belajar memanfaatkan TIK melalui internet, karena akses yang kurang lancar. Lebih lanjut guru Pendidikan Agama Kristen yang tinggal di daerah tersebut, merasa sangat kesulitan ketika harus melaksanakan pembelajaran online. Terkadang pendidik ataupun peserta didik harus berusaha mencari tempat untuk mendapatkan akses internet. Salah seorang guru Pendidikan Agama Kristen yang berada di daerah gunung di provinsi Maluku mengatakan bahwa, untuk bisa melaksanakan pembelajaran online para peserta didik dan para pendidik harus turun ke pesisir pantai. Di pesisir pantai mereka akan mendapatkan akses internet yang sedikit lebih baik dan rutinitas ini menjadi tradisi baru bagi dunia pendidikan terkhusus masyarakat yang tinggal di daerah dengan akses internet yang kurang lancar.

Kedua, sejumlah guru Pendidikan Agama Kristen yang berada di daerah dengan akses internet yang kurang lancar juga mengatakan bahwa pembelajaran online tersebut sulit bahkan sangat sulit untuk diterapkan dalam pembelajaran. Guru Pendidikan Agama Kristen mengatakan bahwa pembelajaran online adalah budaya baru bagi mereka dan belum pernah menggunakan sebelumnya. Bukan sarana prasarana pendukung seperti laptop atau android dan akses internet yang menjadi kendala utama, melainkan pemahaman atau keterampilan guru Pendidikan Agama Kristen dalam mensinergikan teknologi dalam mendukung pembelajaran yang efektif pada abad-21. Salah seorang guru Pendidikan Agama Kristen yang mengajar di SMP Negeri 2 Kairatu BaratMaluku mengatakan bahwa, $100 \%$ guru di sekolah tersebut memiliki perangkat pendukung seperti laptop, android bahkan akses internet cukup baik untuk digunakan. Namun, selama ini perangkat tersebut jarang bahkan tidak pernah digunakan untuk mendukung pembelajaran. Mereka hanya menggunakan perangkat tesebut dalam menyelesaikan segala administrasi kelengkapan guru, perangkat pembelajaran yang dibutuhkan, sedangkan android yang dimiliki lebih digunakan hanya untuk sekedar komunikasi, belum pernah digunakan dalam proses pembelajaran sebelumnya. Kondisi ini tentunya akan mempengaruhi motivasi seorang guru Pendidikan Agama Kristen untuk meningkatkan kompetensinya sebagai guru abad-21.

Ketiga, Sejumlah guru Pendidikan Agama Kristen mengatakan bahwa pembelajaran online sulit diterapkan bukan karena keterbatasan akses internet 
atau sarana pendukung lainnya, namun yang menjadi kendala utama adalah keterbatasan kemampuan dan keterampilan guru Pendidikan Agama Kristen dalam memanfaatkan teknologi. Guru Pendidikan Agama Kristen jarang bahkan tidak pernah mengikuti kegiatan pengembangan kompetensi guru Pendidikan Agama Kristen. Lebih lanjut guru PAK mengatakan bahwa mereka yang tinggal di daerah yang jauh dari pusat kota sangat jarang mendapatkan kesempatan untuk mengikuti kegiatankegiatan pengembangan kompetensi seperti pelatihan atau workshop. Sekolah atau lembaga pendidikan lainnya sangat minim kegiatan. Guru PAK mengatakan bahwa di masing-masing daerah sudah membantuk organisasi-organisasi keguruan seperti Musyawarah Guru Mata Pelajaran (MGMP) PAK, Kelompok Kerja Guru (KKG) PAK dan organisasi yang lainnya. Namun, untuk kebijakan dari setiap oragnisasi tersebut berbeda untuk daerah yang satu dengan daerah yang lainnya. MGMP/KKG yang berada di daerah lebih pasif sehingga ada yang mengadakan pertemuan MGMP/KKG hanya satu kali dalam satu semester, yaitu saat penutupan semester ganjil ataupun genap. Selain itu kegiatan yang selama ini dilaksanakan oleh oraganisasi guru misalnya MGMP atau sekolah hanya sebatas pelatihan pembuatan perangkat pembelajaran (RPP), pembahasan kurikulum, sosialisasi kebijakankebijakan tertentu. Hal ini menjadi alasan utama para guru Pendidikan Agama Kristen mengatakan merasa sangat sulit untuk melaksanakan pembelajaran online pada masa pandmei covid-19. Guru Pendidikan Agama Kristen yang mengatakan sulit, karena mereka belum familiar dengan pembelajaran yang memanfaatkan teknologi, mereka belum pernah mendapatkan bimbingan secara langsung, padahal mereka memiliki fasilitas pendukung seperti laptop ataupun android. Perangkat pendukung seperti laptop hanya dimanfaatkan oleh guru Pendidikan Agama Kristen untuk menyelesaikan administrasi sekolah dan android yang dimiliki oleh guru Pendidikan Agama Kristen hanya digunakan sebagai alat komunikasi.

Keempat, Guru yang mengatakan merasa sulit atau bahkan sangat sulit untuk melaksanakan pembelajaran online, adalah mereka yang belum mengikuti kegiatan Pengembangan Profesi Guru (PPG). Guru yang belum mengikuti kegiatan PPG tentunya belum mendapatkan pembekalan kusus untuk kompetensi dalam pembelajaran abad-21 yaitu pemanfaatan teknologi dalam pembelajaran Pendidikan Agama Kristen. Berbeda dengan guru PAK yang sudah mengikuti kegiatan PPG telah diperlengkapi kompetensi untuk mensinergikan teknologi ke dalam pembelajaran. Bahkan, mereka telah mengikuti pembelajaran daring atau online selama tiga bulan. Ini menjadi salah satu faktor pembeda bagi guru Pendidikan Agama Kristen dalam menerapkan pembelajaran online pada masa darurat pandemi covid-19.

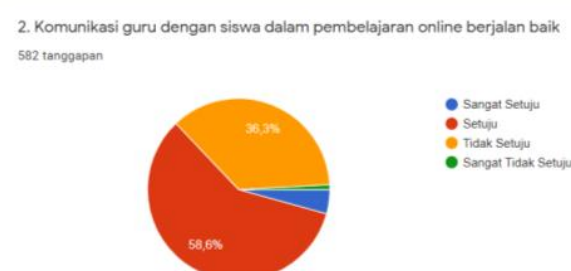

Gambar 2. Rekapitulasi data penelitian persepsi guru PAK terhadap kemudahan komunikasi antara pendidik dengan peserta didik dalam pembelajaran online periode April-Juni 2020

Kemudahan dalam membangun komunikasi yang dimaksud adalah kemudahan dalam membangun interaksi antara pendidik dengan peserta didik dan antara peserta didik dengan peserta didik pada saat pembelajaran online 
berlangsung. Berdasarkan gambar 2 di atas menunjukkan bahwa guru Pendidikan Agama Kristen yang bersedia mengisi kusioner yang dibagikan terdapat 4,3\% atau sebanyak 25 orang guru Pendidikan Agama Kristen yang mengatakan Sangat Setuju bahwa pembelajaran online bisa mempermudah komunikasi peserta didik dengan para pendidik, 58,6\% atau sebanyak 341 orang guru Pendidikan Agama Kristen yang memiliki persepsi Setuju bahwa komunikasi bisa berjalan dengan baik dalam pembelajaran online dan mudah untuk digunakan.

Alasan yang tidak jauh berbeda disampaikan oleh guru Pendidikan Agama Kristen bahwa pembelajaran online sudah menyerupai pembelajaran tatap muka yang selama ini menjadi budaya belajar Indonesia. Ada beberapa faktor yang menjadi alasan bagi guru Pendidikan Agama Kristen tidak kesulitan dalam membangun komunikasi dengan peserta didik dalam pembelajaran online, di antaranya:

Pertama, banyaknya platform pembelajaran online yang tersedia, bisa dimanfaatkan oleh pendidik dan peserta didik dengan mudah karena disediakan secara gratis. Pendidik bisa memilih platform yang sesuai dengan harapannya, sesuai dengan kenyamanan dalam penggunaannya. Dari informasi yang penulis kumpulkan, guru Pendidikan Agama Kristen banyak menggunakan google classroom untuk mendukung pembelajaran online, selanjutnya aplikasi edmodo dan schoology. Lebih lanjut guru Pendidikan Agama Kristen mengatakan platform pembelajaran online yang dilengkapi tersebut memiliki berbagai fitur yang mudah digunakan, bahkan ada fitur untuk membangun komunikasi yang baik dengan para peserta didik. Adanya fitur chat memberikan kebebasan bagi setiap peserta didik untuk memberikan atau menyampaikan pendapat, untuk saling berinteraksi dengan peserta yang lain atau guru. Selain itu, beberapa platform pembelajaran online telah dilengkapi dengan fitur video conference, hal ini sangat membantu pendidik dan peserta didik dalam membangun komunikasi denga guru atau peserta didik yang lainnya.

Kedua, Guru Pendidikan Agama Kristen mengatakan sudah familiar dengan video call melalui WA atau messenger memudahkan guru dalam membangun komunikasi. Kebiasaan yang sadar atau tidak sadar sering kita lakukan seperti video call ternyata bisa mempermudah guru PAK dalam membangun komunikasi dengan peserta didik yang berada di tempat yang berbeda. Lebih lanjut guru PAK mengatakan bahwa selama ini guru PAK sudah ada grup kelas kusus mata pelajaran dengan menggunakan aplikasi whatsaap bahkan media sosial facebook. Hal ini sudah sangat membantu dan memudahkan guru PAK untuk membangun komunikasi jarak jauh dalam pelaksanaan pembelajaran online di masa pandemi covid-19. Lebih lanjut guru Pendidikan Agama Kristen berpendapat bahwa tutorial penggunaan platform pembelajaran online sudah banyak tersedia di internet, baik berupa tulisan atau bahkan dalam format video yang di upload via youtube. Setiap orang bebas mengakses kapan saja atau dimana saja, kondisi ini sangat membantu guru dalam pembelajaran online.

Dari 582 orang guru Pendidikan Agama Kristen ada 36,3\% atau sebanyak 211 orang yang mengatakan Tidak Setuju dan $0,9 \%$ atau sebanyak 5 Guru Pendidikan Agama Kristen yang mengatakan bahwa untuk membangun komunikasi dalam pembelajaran online adalah hal yang sangat sulit untuk dilakukan. Guru yang mengatakan sulit 
dipengaruhi oleh beberapa faktor, di antaranya:

Pertama, guru Pendidikan Agama Kristen masih belum familiar dengan berbagai platform pembelajaran online. Sejumlah guru Pendidikan Agama Kristen mengatakan bahwa mereka sangat kesulitan dalam mengoperasikan atau memahami banyaknya fitur-fitur yang ditampilan pada layar platform pembelajaran online. Lebih lanjut guru Pendidikan Agama Kristen berpendapat bahwa proses mendownload aplikasi yang membutuhkan ruang yang cukup besar, proses registrasi dan verifikasi masih menjadi keluhan banyak pengguna yaitu guru PAK, lebih lanjut guru mengatakan bahwa saat menggunakan platform tersbut juga menjadi kendala yang sulit bagi guru Pendidikan Agama Kristen Indonesia. Kondisi ini membuat para pendidik merasa kesulitan dalam membangun komunikasi yang baik dengan para peserta didik.

Kedua, beberapa guru Pendidikan Agama Kristen memiliki pandangan bahwa pelaksanaan pembelajaran online hanya akan menambah dan membebani pikiran para pendidik. Lebih lanjut lagi, guru Pendidikan Agama Kristen mengatakan bahwa mereka sudah disibukkan oleh berbagai kegiatan di rumah dan pekerjaan yang lainnya, sehingga guru PAK memiliki motivasi yang sangat rendah untuk selalu meningkatkan keterampilannya dalam mengajar.

\section{B. Persepsi Guru PAK terhadap dampak pengunaan pembelajaran online terhadap guru}

Terhadap aspek dampak pembelajaran online pada guru dibagi menjadi 3 aspek, yaitu:

1. Pembelajaran online membuat guru semakin termotivasi untuk mengajar

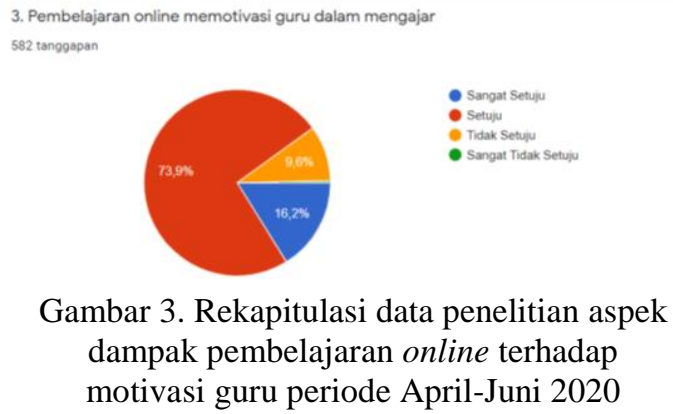

Motivasi dalam hal ini adalah semangat guru untuk melaksanakan pembelajaran online pada masa pandemi covid-19. Dalam dunia pendidikan, terutama dalam kegiatan pembelajaran, bahwa kelangsungan dan keberhasilan proses belajar mengajar bukan hanya dipengaruhi oleh faktor intelektual saja, melainkan juga oleh faktor-faktor nonintelektual lain yang tidak kalah penting dalam menentukan hasil belajar seseorang, salah satunya adalah kemampuan seseorang siswa untuk memotivasi dirinya. Motivasi sangat penting bagi diri seorang guru Pendidikan Agama Kristen dalam melaksanakan pembelajaran, sebab dengan adanya motivasi akan semangat membuat guru semakin semangat dalam mengajar dan sebaliknya kurang adanya motivasi akan melemahkan semangat guru PAK dalam mengajar.

Berdasarkan gambar 2 di atas menunjukkan bahwa sebanyak 582 orang guru Pendidikan Agama Kristen yang bersedia mengisi kuisioner yang dibagikan terdadapat $16,2 \%$ atau sebanyak 94 orang guru Pendidikan Agama Kristen yang mengatakan Sangat Setuju bahwa pembelajaran online mampu memotivasi guru dalam mengjar, $73,9 \%$ atau sebanyak 430 orang guru 
Pendidikan Agama Kristen yang memiliki persepsi Setuju bahwa pembelajaran online mampu memotivasi guru untuk mengajar. Guru Pendidikan Agama Kristen yang setuju mengatakan bahwa pembelajaran online adalah budaya baru untuk sebagian besar lembaga pendidikan Indonesia. Pembelajaran ini juga sangat relevan dengan tuntutan era industri 4.0, dengan demikian guru Pendidikan Agama Kristen harus adaptif, inovatif terhadap tuntutan zaman.

Beberapa faktor yang berdampak terhadap motivasi guru dalam mengajar, di antaranya:

Pertama, Sejumlah guru Pendidikan Agama Kristen mengatakan bahwa sejak pembelajaran jarak jauh, guru Pendidikan Agama Kristen semakin tertantang/bersemangat untuk bisa melaksanakan pembelajaran online seperti guru yang lainnya. Lebih lanjut guru PAK mengatakan, sering menghabiskan waktu untuk belajar dari teman, belajar dari youtube untuk belajar melaksanakan pembelajaran online. mereka tidak merasa malu untuk bertanya, bahkan menghabiskan waktu dan kuota yang tidak sedikit hanya untuk memiliki pemahaman dalam melaksanakan pembelajaran online. Motivasi ini tumbuh dengan sendirinya karena keinginan dan karena tuntutan kebutuhan pembelajaran abad-21.

Kedua, pada masa pandemi banyak aktivitas yang dilaksanakan secara online dengan memanfaatkan teknologi. Demikian halnya dengan banyak lembaga pendidikan tinggi yang ada di Indonesia, melaksanakan berbagai kegiatan secara virtual untuk memperlengkapi guru-guru
Indonesia. Semangat yang dimiliki guru Pendidikan Agama Kristen juga terlihat dari semangat dan keinginan guru Pendidikan Agama Kristen Indonesia dalam mengikuti kegiatan workshop yang dilaksanakan oleh berbagai lembaga pendidikan secara online, baik yang berbayar ataupun yang gratis. Hal ini memberikan dampak positif bagi guru Pendidikan Agama Kristen untuk terus termotivasi dalam meningkatkan kompetensi mereka dalam mengajar.

Ketiga, faktor media sosial juga menjadi alasan banyak guru PAK semakin termotivasi dalam mengajar. Lebih lanjut guru Pendidikan Agama Kristen mengatakan bahwa, banyaknya guru yang mengupload segala karya pembelajaran mereka di masa pandemi membuat guru PAK semakin termotivasi dan ingin seperti mereka. Dengan demikian, guru PAK semakin termotivasi untuk mengajar.

Keempat, Kesadaran guru Pendidikan Agama Kristen akan pentingnya kesehatan juga menjadi faktor utama yang membuat guru memiliki motivasi yang tinggi. Guru PAK menyadari akan bahaya wabah virus corona terhadap tubuh manusia. Lebih lanjut guru PAK mengatakan bahwa mereka menyadari bahwa penyebaran virus corona yang begitu cepat dan tidak mengenal batas usia atau tempat. Virus corona bisa menyerang siapa saja dan kapan saja di waktu yang tidak didugaduga. Kesadaran ini menjadi modal penting bagi seorang guru PAK untuk melaksanakan pembelajaran online. Guru PAK mengatakan demi kesehatan guru, kesehatan peserta didik dan kesehatan 
seluruh masyarakat, guru Pendidikan Agama Kristen harus semakin bersemangat dalam melaksanakan pembelajaran online. Dengan pembelajaran online tentunya akan semakin menghindarkan kita dari virus corona tersebut.

Kelima, sejumlah guru Pendidikan Agama Kristen berpendapat bahwa pembelajaran online memberikan ruang waktu yang lebih banyak untuk mengerjakan banyak hal. Guru PAK perempuan mengatakan bahwa mereka bisa lebih bebas dan punya waktu yang banyak untuk mengerjakan pekerjaan di rumah. Pada intinya, guru Pendidikan Agama Kristen mengatakan bahwa mengajar online bisa sangat fleksibel terhadap tempat dan waktu sehingga memungkinkan setiap orang untuk melakukan banyak hal tanpa harus meninggalkan tugas mengajar.

Keenam, Indahnya kebersamaan bersama keluarga adalah kerinduan banyak orang. Seorang guru yang bekerja atau mengajar dari hari senin sampai jumat, tentunya hanya memiliki sisah waktu satu hari sebagai waktu untuk berkumpul dengan keluarga. Guru Pendidikan Agama Kristen mengatakan semakin termotivasi dalam mengajar dengan pembelajaran online, karena dengan pembelajaran online, guru PAK semakin memiliki banyak waktu untuk berkumpul dengan keluarga. Lebih lanjut guru PAK mengatakan bahwa pembelajaran online memberikan ruang untuk bepergian atau berkunjung ke tempat keluarga yang lain tanpa meninggalkan tugas utama sebagai seorang pendidik.
Dari 582 orang guru Pendidikan Agama Kristen Indonesia ada 9,6\% atau sebanyak 56 orang yang mengatakan Tidak Setuju dan hanya $0,3 \%$ atau sebanyak 2 orang yang mengatakan Sangat Tidak setuju. Hanya ada 58 orang yang mengatakan pembelajaran online tidak membuat guru semakin termotivasi. Alasan guru Pendidikan Agama Kristen mengatakan merasa tidak termotivasi adalah karena diantara guru Pendidikan Agama Kristen sudah berada pada usia 45-51 tahun. Faktor usia menjadi alasan mereka jika harus tetap belajar dengan hal-hal yang baru membuat mereka merasa terbebani, dan merasa tidak sanggup. Selain itu, Faktor kesibukan juga menjadi hal utama yang membuat guru tidak memiliki waktu yang cukup untuk belajar dengan hal-hal yang baru lagi. Dengan demikian, banyak guru PAK yang berharap pembelajaran segera pulih dan melaksanakan pembelajaran tatap muka dan meninggalkan pembelajaran online.

2. Memotivasi guru untuk semakin kreatif

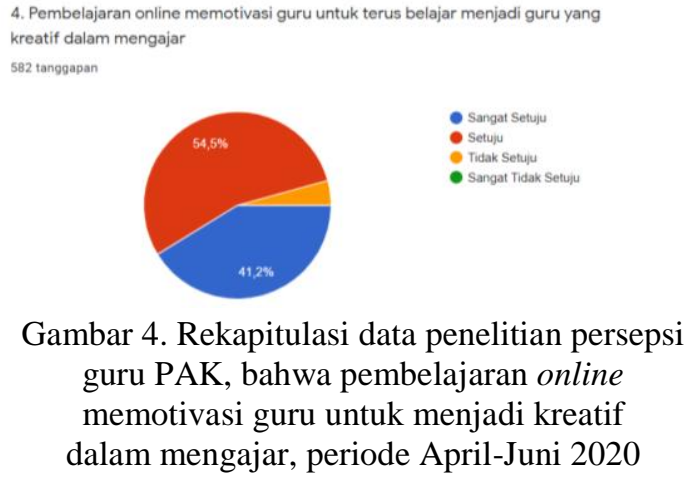

Guru kreatif adalah impian hampir semua guru. Salah satu tuntutan pembelajaran abad-21 adalah kreatifitas pendidik dalam pembelajaran. demikian pembelajaran yang diterapkan pada masa pandemi menuntut kreatifitas guru dalam mendesain pembelajaran agar lebih menarik. Berdasarkan gambar di atas 
menunjukkan bahwa dari 582 guru Pendidikan Agama Kristen yang bersedia mengisi kuisioner yang dibagikan terdadapat $41,2 \%$ atau sebanyak 240 orang guru Pendidikan Agama Kristen yang mengatakan Sangat Setuju bahwa pembelajaran online mampu memotivasi guru untuk semakin kreatif, 54,5\% atau sebanyak 317 orang guru Pendidikan Agama Kristen yang memiliki persepsi Setuju bahwa pembelajaran online mampu memotivasi guru untuk semakin kreatif. Memotivasi guru untuk semakin kreatif yang dimaksud dalam penelitian ini adalah semangat atau keinginan guru untuk mencoba menggunakan pembelajaran yang selama ini belum pernah digunakan, mempelajari apa yang baru untuk mendukung pembelajaran, mengembangkan pembelajaran yang lebih menarik dengan memanfaatkan TIK. Guru Pendidikan Agama Kristen mengatakan bahwa dengan pembelajaran online, guru Pendidikan Agama Kristen semakin termotivasi untuk mencoba halhal yang baru yang belum pernah digunakan. Salah satu contoh pemanfaatan video conference dalam pembelajaran tatap muka secara online. Guru Pendidikan Agama Kristen sudah banyak yang mencoba untuk menggunakannya sekalipun tidak sempurna. Guru PAK mengatakan bahwa pada awal penggunaan media pembelajaran tersebut, guru Pendidikan Agama Kristen masih belum mampu mengendalikan kelas agar peserta didik tidak bising dalam video conference tetapi dengan berani untuk mencoba yang baru sudah menggambarkan bahwa pembelajaran online tersebut sudah memotivasi guru Pendidikan Agama Kristen untuk semakin kreatif.

Dari 582 jumlah responden ada $4,3 \%$ atau sebanyak 25 orang yang mengatakan bahwa pembelajaran online tidak menjadikan guru untuk semakin kreatif. Pembelajaran online justru membuat sejumlah guru Pendidikan Agama Kristen semakin tidak mampu untuk mengajar, bahkan ada guru Pendidikan Agama Kristen yang mengatakan bahwa selama pandemi tidak melaksanakan aktifitas pembelajaran dengan kata lain, peserta didik diliburkan. Banyak guru yang merasa kesulitan dalam menggunakannya, dalam melaksanakan pembelajaran karena belum familiar. Hal ini membuat sejumlah guru Pendidikan Agama Kristen justru semakin meredup dan tidak bisa mengembangkan kreatifitas mengajarnya melalui pembelajaran online. Kurangnya pelatihan yang diikuti oleh guru Pendidikan Agama Kristen, seolah memperparah kondisi pembelajaran pada masa covid-19.

3. Memotivasi guru untuk meningkatkan keterampilan TIK dalam mengajar

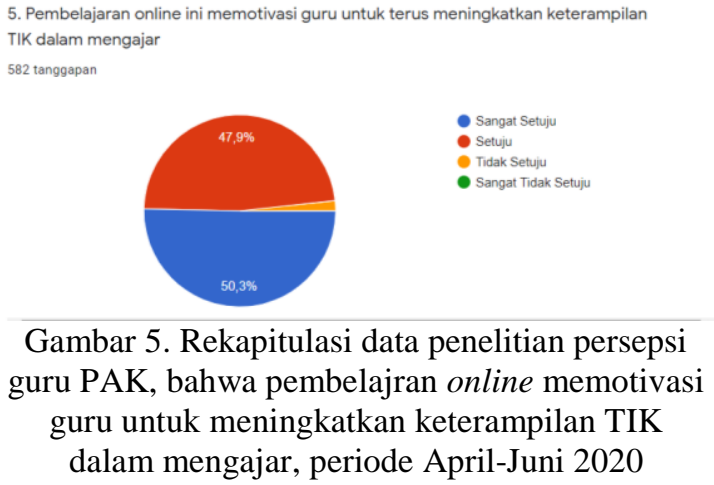

Pembelajaran abad-21 sebagai tuntutan era industri 4.0, ditandai dengan pemanfaatan atau pengintegrasian Teknologi dalam pembelajaran. Teknologi membawa perubahan atau kemajuan yang besar dalam menyelesaikan permasalahan pendidikan terumatama dalam proses belajarmengajar. Sebab itu, guru Pendidikan Agama Kristen harus mempersiapkan diri untuk selalu memperbaharui pengetahuan dan keterampilan mereka dalam 
menggunakan TIK. Guru yang memiliki kemampuan TIK yang baik tentunya akan membuat pembelajaran semakin menarik. Demikian sebaliknya, bagi guru PAK yang memiliki keterampilan pemanafaatan teknologi informasi dan okmunikasi yang terbatas. Terbatasnya kemampuan Teknologi Informasi dan Teknologi guru Pendidikan Agama Kristen masih menjadi masalah utama sebagai penghambat dalam menciptakan pembelajaran yang kreatif dan menarik pada abad-21. Dengan kehadiran wabah corona ditahun 2019 telah membawa transformasi dalam bidang pendidikan Indonesia. Situasi saat ini mengaruskan pendidik, peserta didik bahkan orang tua melek teknologi. Mau atau tidak mau, siap atau tidak siap, para pendidik harus terus berinovasi dalam menciptakan pembelajaran yang inovatif.

Dalam penelitian ini, memotivasi untuk meningkatkan keterampilan Teknologi Informasi dan Teknologi adalah upaya guru Pendidikan Agama Kristen dalam memanfaatkan perangkat teknologi seperti Laptop, Android dalam mendukung pembelejaran. Berdasarkan gambar 5 di atas menunjukkan bahwa dari 582 orang guru Pendidikan Agama Kristen yang bersedia mengisi kusioner yang dibagikan terdadapat $50,3 \%$ atau sebanyak 293 orang guru Pendidikan Agama Kristen yang mengatakan Sangat Setuju bahwa pembelajaran online mampu memotivasi guru untuk meningkatkan keterampilan TIKnya dalam mengajar dan ada 47,9\% atau sebanyak 279 orang guru Pendidikan Agama Kristen yang memiliki persepsi Setuju bahwa pembelajaran online mampu memotivasi guru untuk meningkatkan keterampilan TIKnya dalam mengajar.

Guru Pendidikan Agama Kristen berpendapat bahwa pembelajaran online mendorong atau bahkan memaksan guru
Pendidikan Agama Kristen untuk bisa memanfaatkan perangkat yang dimiliki untuk mendukung pembelajaran. Guru Pendidikan Agama Kristen mengatakan bahwa selama ini laptop hanya digunakan untuk mengerjakan perangkat pembelajaran, namun sekarang guru Pendidikan Agama Kristen telah belajar untuk memanfaatkan laptop untuk melaksanakan pembelajaran. Guru Pendidikan Agama Kristen semakin terampil dalam dalam menggunakan berbagai aplikasi untuk pembelajaran online, bahkan sejumlah guru Pendidikan Agama Kristen mengatakan banyak yang mengembangkan media pembelajaran berbasis teknologi seperti video pembelajaran, buku eletronik, media interaktif yang diupload melalui channel yotube. Situasi ini mendorong bahkan memaksa guru Pendidikan Agama Kristen untuk terus belajar dan mengasah keterampilannya dalam mengguanakn Teknologi Informasi dan Teknologi dalam pembelajaran.

Dari 582 responden ada $1,7 \%$ atau sebanyak 10 orang yang mengatakan bahwa pembelajaran online tidak memotivasi pendidik untuk meningkatkan keterampilannya dalam menggunakan Teknologi Informasi dan Teknologi. Pembelajaran tatap muka yang selama ini dilaksanakan tidak memaksa atau tidak mengharuskan para pendidik untuk melaksanakan pembelajaran dengan menggunakan Teknologi Informasi dan Teknologi. Peraturan sekolah juga yang seolah membiarkan guru untuk tidak melek dengan teknologi, membuat guru Pendidikan Agama Kristen tidak memiliki keinginan untuk belajar menggunakan Teknologi Informasi dan Teknologi. Guru Pendidikan Agama Kristen menghabiskan banyak waktu hanya untuk bermain media sosial facebook. Dengan satu tujuan untuk berinteraksi dengan rekanrekan untuk upload status dan sebagainya, 
namun belum pernah digunakan dalam pembelajaran. Kondisi ini menjadi zona aman bagi banyak guru sehingga banyak guru Pendidikan Agama Kristen yang tidak terampil bahkan tidak bisa menggunakan komputer untuk pembelajaran.

\section{Guru Pendidikan Agama Kristen} cukup memberikan respon positif terhadap pembelajaran online yang sedang diterapkan pada masa darurat wabah virus corona. Persepsi guru PAK terhadap pembelajaran online tentunya akan sangat mempengaruhi kualitas pembelajaran yang akan dilaksanakan. Lebih dari 50\% guru Pendidikan Agama Kristen mengatakan bahwa pembelajaran online mudah untuk digunakan. Kemudahan penggunaannya meliputi: 1) Pembelajaran online bisa diterapkan kapan pun dan dimana pun berada tanpa harus berkumpul di dalam sebuah ruang kelas. Beberapa penelitian sebelumnya mengatakan bahwa pembelajaran online merupakan pembelajaran yang sangat efektif dan relevan digunakan untuk kondisi saat ini, hal ini dikarenakan pembelajaran tetap bisa berlangsung dimana pun berada. ${ }^{22}$ 2) Pembelajaran online bisa berjalan dengan baik hanya dengan menggunakan perangkat elektronik seperti android atau laptop sehingga memudahkan pendidik atau peserta didik. Sebagaimana penelitian sebelumnya mengatakan bahwa mobile memberikan sumbangsih yang besar dalam pelaksanaan pembelajaran jarak jauh atau pembelajaran daring dengan memanfaatkan akses internet yang baik. ${ }^{23}$ Lebih lanjut guru Pendidikan Agama

${ }^{22}$ Sadikin dan Hamidah, "Pembelajaran Daring Di Tengah Wabah Covid-19."

23 Agah Tugrul Korucu dan Ayse Alkan, "Differences between M-Learning (Mobile Learning) dan e-Learning, Basic Terminology dan Usage of m-Learning in Education," Procedia Social dan Behavioral Sciences 15 (2011): 19251930.
Kristen berpendapat bahwa pembelajaran online memberikan kemudahan bagi guru untuk mendesain pembelajaran dengan interaksi yang baik antara pendidik dengan peserta didik, peserta didik dengan peserta didik. Guru Pendidikan Agama Kristen berpendapat bahwa pembelajaran online memberikan kemudahan interaksi melalui chat berupa tek ataupun tatap muka secara virtual dengan aplikasi video conference. Sebagaimana dikatakan oleh Tika Amalia dalam tulisannya bahwa pembelajaran online memberikan kemudahan bagi penggunanya dalam berinteraksi karena dilengkapi dengan berbagai fitur yang menarik seperti room chat, site news bahkan video conference. $^{24}$

Pada pelaksanaan pembelajaran online, guru Pendidikan Agama Kristen memberikan sikap yang positif terhadap pembelajaran online yang diterapkan. Guru Pendidikan Agama Kristen berpendapat bahwa pembelajaran online mampu memberikan stimulus bagi guru Pendidikan Agama Kristen untuk semakin termotivasi dalam melaksanakan pembelajaran. Budaya pembelajaran baru ini membuat para guru semakin penasaran untuk belajar dan terus mencoba. Pembelajaran online memang mampu memotivasi setiap penggunaanya untuk semakin bersemangat dalam memperlajari atau menggunakannya baik guru ataupun para peserta didik. ${ }^{25}$ Secara keseluruhan guru Pendidikan Agama Kristen juga memberikan persepsi yang baik/positif terhadap pembelajaran online. Salah satu Faktor yang berdampak terhadap

\footnotetext{
24 Amelia, "Penggunaan Media Pembelajaran Berbasis E-Learning Studi Persepsi Dan Harapan Dosen Dan Mahasiswa Jurusan Pendidikan Ekonomi Fakultas Ekonomi Universitas Negeri Padang.'

25 Wicaksana, "Efektifitas Pembelajaran Menggunakan Moodle Terhadap Motivasi Dan Minat Bakat Peserta Didik di Tengah Pdanemi Covid -19."
} 
tingginya motivasi guru dalam mengajar online adalah kesadaran guru PAK akan pentingnya kesehatan, demikian halnya akan indahnya kebersamaan keluarga menjadi modal penting untnuk keharmonisan keluarga. Dengan demikian, pembelajaran online mampu memberikan guru PAK untuk semakin memiliki waktu dengan keluarga, dan pembelajaran online juga bisa memutus mata rantai penyebaran virus corona.

Guru Pendidikan Agama Kristen berpendapat bahwa melalui pembelajaran online guru Pendidikan Agama Kristen semakin termotivasi untuk menjadi guru yang kreatif dalam mengajar. Guru Pendidikan Agama Kristen mengatakan, mereka semakin termotivasi untuk selalu berusaha mencoba dan terus belajar menggunakan apa yang sebelumnya mereka belum pernah gunakan dan mencoba apa yang menurut mereka mampu menjadikan pembelajaran lebih menarik. Persepsi yang baik ini tentunya menjadi modal yang sangat penting bagi guru Pendidikan Agama Kristen Indonesia untuk terus meningkatkan kreatifitasnya dalam mengajar, karena abad-21 menuntut guru untuk semakin kreatif dan terus meningkatkan kreatifitasnya dalam mengajar. Hal ini sejalan dengan pernyataan Trilling dan Fadel dalam E.Wijaya 26 yang mengatakan bahwa guru yang kreatif menjadi salah satu tuntutan pendidikan abad-21. Mayoritas guru Pendidikan Agama Kristen semakin termotivasi untuk semakin meningkatkan keterampilanya dalam menggunakan Teknologi Informasi dan Teknologi dalam pembelajaran. Guru Pendidikan Agama Kristen semakin

\footnotetext{
${ }^{26}$ Etistika Yuni Wijaya, Dwi Agus Sudjimat, dan Amat Nyoto, "Transformasi Pendidikan Abad 21 Sebagai Tuntutan Pengembangan Sumber Daya Manusia di Era Global," Prosiding Seminar Nasional Pendidikan Matematika, Vol.1, (2016): 263-278.
}

belajar untuk memanfaartkan Teknologi Informasi dan Teknologi untuk mendukung pembelajaran baik melalui teman, belajar dari youtube atau bahkan melalui kegiatan pelatihan/workshop secara kovensional ataupun virtual. Sebagaimana dikatakan oleh Ambarita bahwa kegiatan peningkatan kreatifitas bisa dilaksanakan secara dan membawa dampak yang sangat baik bagi para pesertanya.

\section{Kesimpulan}

Pembelajaran online bukanlah hal yang baru bagi dunia pendidikan di Indonesia. Sejumlah lembaga pendidikan di Indonesia sudah menerapkan pembelajaran online jauh sebelum kehadiran virus corona. Namun, kemunculan wabah pandemi covid-19 ini semakin mempercepat implementasi pembelajaran abad-21 sebagai tuntutan era industri 4.0. Pada masa pandemi banyak platform pembelajaran online yang bisa dimanfaatkan oleh guru secara gratis ataupun memanfaatkan platform yang berbayar. Pembelajaran online ini telah diterapkan mulai dari lembaga pendidikan tinggi hingga pendidikan anak usia dini. Secara kusus juga untuk aktivitas pembelajaran Pendidikan Agama Kristen pada masa pandemi sungguh variatif. Namun, pada pelaksanaannya mayoritas guru Pendidikan Agama Kristen telah melaksanakan pembelajaran online sejak bulan April sampai akhir semester pada bulan Juni 2020. Pada awal pelaksanaan pembelajaran online di penghujung akhir semester, pengkajian lebih dalam pada segi persepsi guru Pendidikan Agama Kristen sangat diperlukan sebagai bahan evaluasi lebih lanjut untuk pembelajaran Pendidikan Agama Kristen.

Pembelajaran online yang dilaksanakan oleh banyak lembaga pendidikan mendapat respon yang positif 
dari guru Pendidikan Agama Kristen Indonesia. Secara keseluruhan guru Pendidikan Agama Kristen telah banyak yang melaksanakan pembelajaran online. Pada intinya pembelajaran online bukanlah hal yang begitu sulit untuk diterapkan oleh banyak guru Pendidikan Agama Kristen dalam proses pembelajaran di masa pandemi. Demikian halnya dalam membangun komunikasi dengan peserta didik ataupun sesame peserta didik tetap bisa diakomodir melalui pembelajaran online. Selain itu, pembelajaran online juga membuat guru Pendidikan Agama Kristen semakin termotivasi dalam mengajar, guru Pendidikan Agama Kristen semakin memberikan semangat untuk menjadi guru Pendidikan Agama Kristen yang kreatif bahkan guru PAK semakin termotivasi untuk meningkatkan keterampilannya dalam menggunakan TIK. Akan tetapi karena baru awal pelaksanaan, ada banyak kendala yang dihadapi oleh guru Pendidikan Agama Kristen membuat beberapa guru merasa kesulitan untuk melaksanakan pembelajaran online. Namun, secara keseluruhan dapat disimpulkan bahwa guru Pendidikan Agama Kristen memberikan respon yang positif terhadap pembelajaran online yang dilaksanakan pada masa pandemi covid-19.

Persepsi guru Pendidikan Agama Kristen yang positif sangat membantu pelaksanaan pembelajaran online pada masa pandemi covid-19. Namun, kenyataannya guru PAK yang belum mengikuti PPG di dua tahun terakhir cenderung merasa kesulitan dalam pelaksanaan pembelajaran online. Demikian halnya guru PAK yang berada di daerah dengan akses internet yang kurang lancar juga merasa kesulitan di saat mengharuskan pembelajaran dari rumah. Dan hal yang terakhir adalah pengetahuan dan keterampilan guru PAK yang terbatas dalam mensinergikan pemanfaatan TIK dalam pembelajaran.

\section{Saran}

Berdasarkan hasil dan pembahasan penelitian ini, maka penulis menyampaikan beberapa saran penting untuk peningkatakan pembelajaran Pendidikan Agama Kristen pada abad-21, sebagai berikut:

1. Guru Pendidikan Agama Kristen harus terbuka dan adaptif terhadap perkembangan teknologi untuk mendukung pembelajaran.

2. Guru PAK harus secara terus-menerus memperbaharui ilmu pengetahuan dan keterampilannya dalam mengajar baik melalui rekan kerja, melalui youtube atau berbagai kegiatan pelaihan lainnya.

3. Menjadi perhatian utama bagi organisasi-organisasi perkumpulan guru seperti Musyawarah Guru Mata Pelajaran (MGMP) PAK ataupun Kelompok Kerja Guru (KKG) dan organisasi lainnya untuk melaksanakan berbagai kegiatan untuk mengembangkan kompetensi guru PAK.

4. Lembaga pendidikan swasta ataupun negri hendaknya rutin melakukan kegiatan-kegiatan yang bermanfaat terutama dalam pemanfaatan teknologi dalam pembelajaran, sehingga guruguru Indonesia mampu menjawab tuntutan pendidikan abad-21.

5. Kementerian Agama RI Bimas Kristen pusat maupun daerah, memberikan ruang bagi guru Pendidikan Agama Kristen untuk meningkatkan keterampilan dan kompetensi guru PAK melalui berbagai kebijakan pelatihan/workshop yang dilaksanakan secara rutin.

6. Kementerian Agama RI Bimas Kristen pusat dan daerah hendaknya memiliki 
kebijakan yang sama, sehingga semua guru PAK yang tersebar di seluruh wilayah Indonesia bisa menikmati kebijakan dan kesempatan yang sama.

\section{Referensi}

Abidin, A.Z., T. Puspasari, dan W.A. Nugroho. "Polymers for Enhanced Oil Recovery Technology.” Procedia Chemistry 4 (2012): 11-16.

Ambarita, Jenri, Hendra Helwaun, dan Lauraincia Van Houten. "Workshop Pembuatan E-Book Sebagai Bahan Ajar Elektronik Interaktif Untuk Guru Indonesia Secara Online Di Tengah Covid 19." Community Engagement \& Emergence Journal Vol.2, No.1 (2020): 44-57.

Ambarita, Jenri, Muthoharoh, dan Ester Yuniati. "Persepsi Masyarakat Terhadap Penggunaan Teknologi Dalam Seminar Online Di Masa Covid-19." Indonesian Journal of Instructional Vol.1 (2020): 1-8. https://journal.kurasinstitute.com/ind ex.php/ijit/article/view/39.

Darmayanti, Tri, Made Yudhi Setiani, dan Boedhi Oetojo. "E-Learning Pada Pendidikan Jarak Jauh: Konsep yang Mengubah Metode Pembelajaran di Perguruan Tinggi di Indonesia." Jurnal Pendidikan Terbuka dan Jarak Jauh 8 (2007): 99-113.

Debora, Kiki, dan Chandra Han. "Pentingnya Peranan Guru Kristen Dalam Membentuk Karakter Siswa Dalam Pendidikan Kristen: Sebuah Kajian Etika Kristen." Diligentia: Journal of Theology and Christian Education 2, No. 1, (January 2020): $1-14$.

"EcoGen Penggunaan Media Pembelajaran Berbasis E-Learning Studi Persepsi dan Harapan Dosen dan Mahasiswa EcoGen Penggunaan Media Pembelajaran Berbasis $e$ -
Learning Studi Persepsi dan Harapan

Dosen dan Mahasiswa" Vol.1 (2018).

Firman, Firman, dan Sari Rahayu. "Pembelajaran Online Di Tengah Pandemi Covid-19." Indonesian Journal of Educational Science (IJES) Vol.2, No.2 (2020).

Kemendikbud Republik Indonesia. "Surat Edaran Nomor 14 2019” (2019): 2.

"Naskah Pidato Sesuai Pengucapan Presiden Joko Widodo Di Depan Sidang Paripurna MPR RI." Kompas.Com. Last modified 2019. https://jeo.kompas.com/naskahlengkap-pidato-presiden-jokowidodo-dalam-pelantikan-periode2019-2024.

Korucu, Agah Tugrul, dan Ayse Alkan. "Differences between M-Learning (Mobile Learning) and e-Learning, Basic Terminology and Usage of $\mathrm{m}$ Learning in Education." Procedia Social and Behavioral Sciences Vol.15 (2011): 1925-1930. http://dx.doi.org/10.1016/j.sbspro.20 11.04.029.

McGrath, Jason, dan John Fischetti. "What If Compulsory Schooling Was a 21st Century Invention? Weak Signals from a Systematic Review of the Literature." International Journal of Educational Research Vol.95 (November 2019): 212-226.

https://doi.org/10.1016/j.ijer.2019.02 .006 .

Mochammad Iskarim. "Dekadensi Moral Di Kalangan Pelajar (Revitalisasi Strategi PAI Dalam Menumbuhkan Moralitas Generasi Bangsa)." Edukasia Islamika Vol.1, No.1 (2016): 1-20.

Ningrum, Diah. "Kemerosotan Moral Di Kalangan Remaja: Sebuah Penelitian Mengenai Parenting Styles Dan 
Pengajaran Adab Diah Ningrum Sekolah Menengah Islam Terpadu (SMIT) Al Marjan." Unisia XXXVII, No.82 (2015): 18-30.

Nuhamara, Daniel. "Pengutamaan Dimensi Karakter dalam Pendidikan Agama Kristen." Jurnal Jaffray Vol.16, No.1 (2018): 93.

Pakpahan, Roida, dan Yuni Fitriani. "Analisa Pemanfaatan Teknologi Informasi dalam Pembelajaran Jarak Jauh Di Tengah Pandemi Virus Corona Covid-19." Journal of Information System, Applied, Management, Accounting and Research Vol.4, No.2 (2020).

Priyanto, Dwi. "Pengembangan Multimedia Pembelajaran Berbasis Komputer" Vol.14, No.1 (2009): 113.

Pujiasih, Erna. "Membangun Generasi Emas dengan Variasi Pembelajaran Online Di Masa Pandemi Covid-19 Building a Golden Generation By Applying Various Online Learning in the Pandemi of Covid-19." Jurnal Karya Ilmiah Guru Vol.5, No.1 (2020): 42-48.

Putrawangsa, Susilahudin, dan Uswatun Hasanah. "Integrasi Teknologi Digital dalam Pembelajaran Di Era Industri 4.0." Jurnal Tatsqif Vol.16, No.1 (2018): 42-54.

Sadikin, Ali, dan Afreni Hamidah. "Pembelajaran Daring di Tengah Wabah Covid-19." Biodik Vol.6, No. 2 (2020): 109-119.

Saifuddin, Much. Fuad. "E-Learning dalam Persepsi Mahasiswa." Jurnal
Varidika Vol.29, No.2 (2018): 102109.

Suwarto, Suwarto, dan Hulman Fajri. "Persepsi Orang Tua Terhadap Proses Bimbingan Belajar Anak Di Rumah." Susunan Artikel Pendidikan Vol.3, No.1 (2018).

Tias, Fauziah Wahyuning. "Perlukah Mahasiswa Akuntansi Strata Satu Akuntansi Di Indonesia Memiliki Persepsi Audit Forensik." Jurnal Akuntansi UNESA Vol.1, No.1 (2012): 1-20.

Utami, Dina. "Efektifitas Animasi Dalam Pembelajaran." Majalah Ilmiah Pembelajaran Vol.7, No.1 (2011): 44-52.

Wicaksana, Ervan. "Efektifitas Pembelajaran Menggunakan Moodle Terhadap Motivasi dan Minat Bakat Peserta Didik di Tengah Pandemi Covid -19." EduTeach: Jurnal Edukasi dan Teknologi Pembelajaran Vol.1, No.2 (2020).

Wijaya, Etistika Yuni, Dwi Agus Sudjimat, dan Amat Nyoto. "Transformasi Pendidikan Abad 21 Sebagai Tuntutan Pengembangan Sumber Daya Manusia di Era Global." Prosiding Seminar Nasional Pendidikan Matematika, 263-278.

Yunita, Dwi, dan Astuti Wijayanti. "Pengaruh Media Video Pembelajaran terhadap Hasil Belajar IPA Ditinjau dari Keaktifan Siswa." Sosiohumaniora: Jurnal Ilmiah Ilmu Sosial dan Humaniora Vol.3, No.2 (2017): 153-160. 